\title{
Prediksi Pelayanan Pelanggan, Kualitas Produk, Kebijakan Harga, Fisik Toko, Dan Kesadaran Terhadap Loyalitas Melalui Kepercayaan Pengecer Sebagai Mediasi Di IKEA Alam Sutera
}

\author{
Rae Nitta Wandriani dan Herlina Budiono \\ Program Studi Manajemen, Fakultas Ekonomi dan Bisnis, Universitas Tarumanagara Jakarta \\ Email: reanitta.wandriani@gmail.com
}

\begin{abstract}
The purpose of this study is to examine whether customer service, product quality, pricing policy, physical store, and awareness can predict loyalty with the retailer trust as a mediation variable at IKEA Alam Sutera. The sample was selected using a convenience sampling method, amounting to 150 respondents at Universitas Tarumanagara. The results of this study indicate that customer service has a significant positive prediction of loyalty through retailer trust as a mediating variable, product quality has a significant negative prediction of loyalty through retailer trust as a mediating variable, price policy has a significant positive prediction of loyalty through retailer trust as mediation variable, physical store has a significant positive prediction of loyalty through retailer trust as a mediating variable, and awareness has a significant positive prediction of loyalty through retailer trust as a mediating variable.
\end{abstract}

Keywords: Customer Service, Product Quality, Awareness, Retailer Trust, Loyalty.

\begin{abstract}
Abstrak: Tujuan penelitian ini adalah untuk menguji apakah pelayanan pelanggan, kualitas produk, kebijakan harga, fisik toko, dan kesadaran dapat memprediksi loyalitas dengan variabel mediasi kepercayaan pengecer pada IKEA Alam Sutera. Sampel dipilih dengan menggunakan metode convenience sampling yang berjumlah 150 responden di Universitas Tarumanagara. Hasil penelitian ini menunjukkan bahwa pelayanan pelanggan memiliki prediksi positif yang signifikan terhadap loyalitas melalui kepercayaan pengecer sebagai variabel mediasi, kualitas produk memiliki prediksi negatif yang signifikan terhadap loyalitas melalui kepercayaan pengecer sebagai variabel mediasi, kebijakan harga memiliki prediksi positif yang signifikan terhadap loyalitas melalui kepercayaan pengecer sebagai variabel mediasi, fisik toko memiliki prediksi positif yang signifikan terhadap loyalitas melalui kepercayaan pengecer sebagai variabel mediasi, dan kesadaran memiliki prediksi positif yang signifikan terhadap loyalitas melalui kepercayaan pengecer sebagai variabel mediasi.
\end{abstract}

Kata kunci: Pelayanan Pelanggan, Kualitas Produk, Kebijakan Harga, Fisik Toko Kesadaran, Kepercayaan Pengecer, Loyalitas.

\section{LATAR BELAKANG}

Kebutuhan rumah tangga sangat dibutuhkan oleh masyarakat setiap hari nya, pada era milenial seperti ini anak muda banyak mendekorasi ruangan kamar, kerja, dan lain-lainnya dengan kreativitas masing-masing orang. Terdapat banyak jenis inspirasi untuk mendekor ruangan di internet dan menarik perhatian masyarakat untuk mendapatkan ruangan yang nyaman untuk melakukan aktivitas. Perabotan rumah selalu diperlukan setiap saat dengan desain yang selalu di perbaharui, serta harga yang semakin murah karena bahan baku yang semakin banyak ditemukan. IKEA menyediakan perlengkapan dan peralatan untuk mengisi rumah dan 
memperindah dengan desain yang terkini dan harga yang terjangkau. IKEA bekerja keras untuk mencapai kualitas dengan harga terjangkau untuk pelanggannya dengan memaksimalkan seluruh rangkaian nilai, dengan menciptakan hubungan kerjasama pemasok dalam jangka panjang, investasi dalam produksi secara otomatis dan memproduksi barang dalam jumlah besar. IKEA ingin menciptakan kehidupan sehari-hari yang lebih baik bagi semua orang yang terkena dampak bisnisnya. IKEA sebagai bidang industri retail memiliki peran yang dapat membentuk toko supaya lebih banyak orang yang akan melakukan pembelian ulang karena merasa puas dengan pelayanan yang baik, kualitas produk yang dapat dipercaya, harga yang terjangkau, bentuk fisik toko yang nyaman untuk dikunjungi dan kesadaran toko yang tinggi untuk membuat pelanggan berkesan. Pentingnya pengaruh tersebut bertujuan untuk meningkatkan kenaikan pengunjung dan melakukan pembelian di IKEA dengan harapan pelanggan yang sudah melakukan pembelian akan melakukan pembelian ulang dan memberitahukan IKEA kepada orang sekitar yang menjadikan IKEA semakin bertumbuh besar.

\section{KAJIAN TEORI}

Gambaran Umum Teori. Loyalitas pelanggan adalah tujuan penting untuk perencanaan pemasaran strategis dan merupakan dasar penting untuk mengembangkan keunggulan kompetitif yang berkelanjutan. Loyalitas pelanggan dapat mengarah pada peningkatan nilai bisnis dan menjaga biaya bisnis tetap rendah. Peningkatan nilai dan penghematan biaya berarti membantu perusahaan untuk mencari pelanggan baru dengan waktu yang lebih rendah. Banyak terdapat definisi dari para ahli tentang kesetiaan memiliki dua kesamaan yaitu: aspek perilaku dan aspek sikap yang terkait dengan loyalitas. Loyalitas perilaku adalah transaksi berulang yang dilakukan pelanggan terhadap toko yang memberikan bukti tidak hanya sekedar harapan. Loyalitas sikap memiliki efek positif pada hubungan, dan kecenderungan untuk terus bertahan dalam hubungan. Loyalitas adalah pengabdian dari pihak pembeli untuk menjaga hubungan untuk membeli produk atau layanan yang berulang. Loyalitas dengan demikian memiliki komponen perilaku yang menunjukkan niat pembelian kembali tetapi juga mencakup komponen sikap yang didasarkan pada preferensi dan pada kesan pelanggan atau partner. Menurut Fornell (1992) bahwa loyalitas dapat diukur dengan minat pembelian kembali dan toleransi harga. Loyalitas di definisikan sejauh mana konsumen ingin membeli produk atau layanan dari perusahaan atau toko yang menyediakan produk. Menurut Pearson (1996) telah mendefinisikan loyalitas sebagai pola pikir pelanggan yang memiliki sikap saling menguntungkan antara pelanggan terhadap perusahaan, pelanggan akan berkomitmen untuk membeli kembali produk atau layanan perusahaan, dan merekomendasikan produk atau layanan kepada orang lain.

Definisi Konseptual Variabel. Pelayanan pelanggan yang baik akan membantu pengunjung untuk mencari informasi yang mereka butuhkan dan membuat pelanggan nyaman untuk mengunjungi toko karena merasa sangat terbantu dengan pelayanan pelanggan (customer service) yang ada. (Parasuramanet et al., 1988; Cronin dan Taylor, 1992., Levy dan Weitz, 2007., Kursunluoglu, 2011).

Pelanggan akan merasa puas jika kualitas produk yang diberikan suatu toko sangat baik, dan pelanggan akan melakukan pembelian kembali pada toko yang sama di karenakan pelanggan merasa percaya pada kualitas yang ditawarkan toko. (Garvin, 2017., Kotler dan Armstrong, 2012., Garvin, 1987., Kotler dan Keller, 2012).

Harga dapat dikatakan sebagai apa yang diserahkan atau dikorbankan untuk memperoleh layanan atau produk, dan kebijakan harga juga dapat dikatakan sebagai jumlah uang yang 
dibebankan untuk suatu produk atau layanan, jumlah nilai yang ditukar pelanggan dengan manfaat memiliki atau menggunakan produk atau layanan. (Monroe, Grewal dan Krishnan, 1998., Bell et al., 1998., Dabholkar et al., 1996; Koschate-Fischer et al., 2014).

Fisik toko penempatan suatu barang sangat berdampak untuk toko tersebut karena pelanggan akan merasa tertarik dan mudah untuk mencarinya. (Ailawadi dan Keller, 2004; Keller, 2010., Baker et al., 2002., Sorensen, 2009a).

Kesadaran pada merek berdampak untuk pelanggan dan dengan mudah pelanggan untuk mengambil keputusan. (Londoño et al, 2016., Keller, 2001., Chunget et al., 2013; Huang dan Sarigollu, 2011; Norazah, 2013a).

Kepercayaan pengecer menunjukkan kepercayaan terhadap merek atau keseluruhan toko yang dapat menimbulkan loyalitas pada pelanggan, sehingga dapat menguntungkan perusahaan. (Chaudhuri dan Holbrook, 2001; Delgado-Ballester dan Munuera-Alemán, 2001, 2005. Palmatieret et al., 2007; Scheerand Stern, 1992).

Loyalitas adalah sikap dimana perilaku atau sikap pelanggan yang dapat menguntungkan perusahaan dengan sendirinya. (Oliver, 1997., Bowen dan Chen, 2001., Hartmann dan Ibanez, 2007).

Kaitan antara Pelayanan Pelanggan dengan Kepercayaan Pengecer. Dalam penelitian, Anselmsson J, Burt S, \& Tunca B (2017) menyatakan bahwa adanya kaitan yang signifikan positif antara pelayanan pelanggan dengan kepercayaan pengecer.

Berdasarkan penelitian yang dilakukan oleh Emel Kursunluoglu (2014) menjelaskan bahwa menyimpulkan bahwa pelayanan pelanggan memiliki pengaruh untuk loyalitas. Tingkat pelayanan pelanggan yang ditawarkan tergantung pada beberapa kriteria seperti karakteristik pengecer, layanan yang ditawarkan oleh pesaing, jenis barang yang ditawarkan, citra harga toko, pendapatan pasar target, dan biaya penyediaan layanan.

Kaitan antara Kualitas Produk dengan Kepercayaan Pengecer. Dalam penelitian, Anselmsson J, Burt S, \& Tunca B (2017), dijelaskan bahwa kualitas produk memiliki kaitan yang signifikan positif terhadap kepercayaan pengecer karena kualitas produk adalah salah satu faktor yang dapat mendukung terciptanya kepuasan pelanggan karena produk yang dibeli dengan kualitas baik.

Berdasarkan penelitian Shih-Tse Wang, E., \& Tsai, B. K. (2014) menjelaskan kepercayaan pengecer adalah kepercayaan konsumen bahwa pengecer menyediakan produk atau layanan yang telah dibayarkan oleh konsumen.

Kaitan antara Kebijakan Harga dengan Kepercayaan Pengecer. Menurut Lombart, C., \& Louis, D. (2014) adanya kaitan yang signifikan positif anatara kebijakan harga dengan kepercayaan pengecer, Individu akan menyimpulkan kebijakan harga dari pemasok berdasarkan persepsi pelanggan tentang tingkat harga awal dari penjualan pengecer yang mereka tahu atau sering dengar dan biasanya relatif terhadap harga di tempat penjualan lainnya dan pengecer yang bersaing di wilayah perdagangan yang sama.

Dalam penelitian Anselmsson J, Burt S, \& Tunca B (2017) Persepsi harga toko adalah faktor utama yang diperhatikan oleh para pengecer merek karena harga merupakan independen dari asosiasi, kemudian pelanggan juga mengambil harga menjadi pertimbangan sebelum melakukan pembelian dari pengecer. 
Kaitan antara Fisik Toko dengan Kepercayaan Pengecer. Menurut Alsaif, T. M., \& Ghoneim, A. (2015) menjelaskan bahwa kemampuan yang membedakan karakteristik satu pengecer dari pengecer lain dalam keberhasilannya melakukan transaksi komersial dapat dibantu dengan fisik toko yang meyakinkan.

Dan penelitian menurut Anselmsson J, Burt S, \& Tunca B (2017) menjelaskan bahwa fisik toko adalah skala yang dapat membentuk persepsi pelanggan dari penampilan fisik toko tersebut yang merupakan aspek kunci dari merek pengecer keseluruhan mengingat bahwa asosiasi toko fisik berkontribusi ekuitas merek karena mereka memprediksi niat konsumen.

Kaitan antara Kesadaran dengan Kepercayaan Pengecer. Dalam penelitian Das, G (2016) dijelaskan bahwa kesadaran dapat membantu pembeli mengenali kondisi pengecer seperti pengakuan toko, dan penarikan toko.

Menurut Anselmsson J, Burt S, \& Tunca B (2017) kesadaran memiliki keterkaitan yang signifikan terhadap kepercayaan pengecer yaitu merupakan langkah awal dalam membangun ekuitas merek, diikuti oleh asosiasi merek, respons merek, dan loyalitas merek. Penelitian ini menguji kesadaran yang dapat mempertahankan kepercayaan pengecer sebagai mediator.

Kaitan antara Kepercayaan Pengecer dengan Loyalitas. Dalam penelitian Rubio N, Villaseñor N \& Yagüe M.J, menjelaskan bahwa adanya kaitan positif yang signifikan antara Kepercayaan Pengecer dengan Loyalitas.

Dan menurut penelitian Anselmsson J, Burt S, Tunca B (2017), dijelaskan bahwa adanya kaitan yang signifikan positif antara Kepercayaan Pengecer sebagai mediasi dengan Loyalitas. Penelitian ini menjelaskan karena adanya kepercayaan yang tinggi maka terkait langsung dengan Loyalitas, kepercayaan menjadi sikap dan respon secara keseluruhan yang menghubungkan citra merek dan kinerja untuk loyalitas.

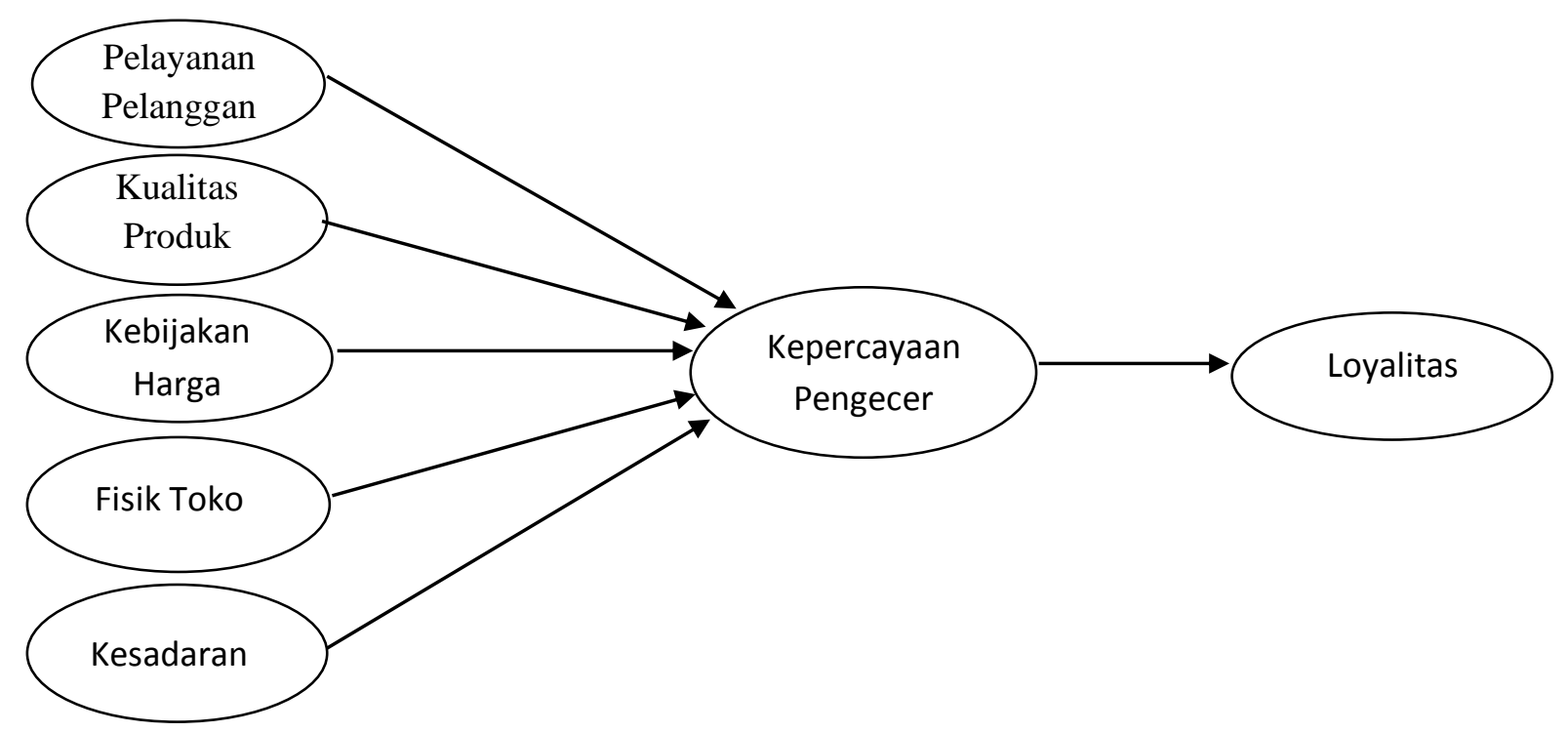

Gambar 1. Model Penelitian

Dari kajian teori, kerangka berpikir, dan model penelitian di atas, dapat diperoleh hipotesis penelitian sebagai berikut: 
H1: Pelayanan Pelanggan merupakan prediksi yang signifikan dengan Kepercayaan Pengecer pada pelanggan IKEA di Alam Sutera.

H2: Kualitas Produk merupakan prediksi yang signifikan dengan Kepercayaan Pengecer pada pelanggan IKEA di Alam Sutera.

H3: Kebijakan Harga merupakan prediksi yang signifikan dengan Kepercayaan Pengecer pada pelanggan IKEA di Alam Sutera.

H4: Fisik Toko merupakan prediksi yang signifikan dengan Kepercayaan Pengecer pada pelanggan IKEA di Alam Sutera.

$\mathrm{H}_{5}$ : Kesadaran merupakan prediksi yang signifikan dengan Kepercayaan Pengecer pada pelanggan IKEA di Alam Sutera.

$\mathrm{H}_{6}$ : Kepercayaan Pengecer dapat memprediksi mediasi yang signifikan dengan Loyalitas pada

pelanggan IKEA di Alama Sutera.

\section{METODOLOGI}

Desain penelitian yang digunakan pada penelitian ini adalah desain penelitian deskriptif. Menurut Malhotra (2010:106) pada bukunya yang berjudul Marketing Research: an applied orientation, penelitian deskriptif adalah jenis penelitian konklusif yang memiliki tujuan utama yaitu mendeskripsikan sesuatu berupa karakteristik atau fungsi pasar. Penelitian ini dibuat dengan tujuan untuk menguji secara empiris prediksi antara pelayanan pelanggan, kualitas produk, kebijakan harga, fisik toko, dan kesadaran sebagai variabel dependen, kepercayaan pengecer sebagai variabel mediasi dan loyalitas sebagai variabel independen. Metode yang digunakan dalam penelitian ini adalah Cross Sectional Design. Menurut Malhotra (2010:108) Cross Sectional Design adalah jenis desain penelitian yang melibatkan pengumpulan informasi dari sampel tertentu dalam elemen populasi hanya sekali. Dengan metode kuantitatif dan pengumpulan data menggunakan kuesioner yang menggunakan skala likert 1-5.

Populasi yang digunakan untuk penelitian ini adalah seluruh pelanggan IKEA yang terdapat di Universitas Tarumanagara. Ukuran sampel menurut Roscoe (1975) penelitian yang layak dengan menggunakan responden sebanyak 30 sampai 500 sampel. Jadi jumlah sampel yang digunakan pada penelitian ini adalah sebanyak 150 sampel karena semakin besar sampel yang digunakan maka akan semakin akurat hasil dari suatu penelitian.

Pengumpulan data dilakukan menggunakan kuesioner dengan skor berupa skala likert. Data dianalisis menggunakan PLS-SEM dimana data diolah dengan program software SmartPLS 3. Pengolahan data yang pertama dilakukan pada outer model untuk menguji validitas dan reliabilitas. Uji validitas dilihat dari nilai Average Variance Extracted $>0,5$ (Hair, Ringle, \& Sarstedt, 2011) dan nilai loading factor > 0,7 (Henseler et al., 2009) maka masih dianggap cukup. Pengolahan data selanjutnya yaitu uji reliabilitas dilihat dari besarnya nilai pada cronbach alpha dan composite reliability harus diatas 0,6 suatu data yang digunakan dapat dinyatakan memiliki reliabilitas.

Pengolahan data yang kedua, yaitu dilakukan pada inner model untuk menguji hipotesis yang telah dihasilkan. Pengujian konstruk penelitian yang pertama dilakukan dengan melihat nilai $\mathrm{R}$-square $\left(\mathrm{R}^{2}\right)$ dengan kriteria 0,67 yang berarti bersifat substansial, 0,33 yang berarti bersifat moderat, dan 0,19 yang berarti bersifat lemah (Henseler, Ringle \& Sinkovics, 2009). Nilai dari effect size $\left(\mathrm{f}^{2}\right)$ dinyatakan sebesar 0,$02 ; 0,15$ dan 0,35 dengan masing-masing variabel yang menandakan kecil, sedang, dan besar (Henseler, J., Ringle, C. M., \& Sinkovics, R. R., 2009). Nilai dari Predictive Relevance $\left(\mathrm{Q}^{2}\right)$ yang dapat dilihat melalui blindfolding yaitu >0 
adalah berupa $0,02,0,15,0,35$ untuk relevansi prediktif yang lemah, sedang, kuat. Selanjutnya pengujian melalui mediasi yaitu t-statistics $>1,96 ; \alpha=5 \%$, untuk mengetahui penggunaan full mediation atau partial mediation (MacKinnon, Fairchild, \& Fritz, 2007). Pengujian hipotesis menggunakan t-statistics dalam penelitian ini lebih kecil daripada 1,96 (t-value $=<1,96)$,

Variabel dan jumlah pernyataan yang digunakan dan yang akan diolah datanya dalam penelitian ini, tersaji dalam tabel 1 berikut ini:

Tabel 1. Konstruk Penelitian

\begin{tabular}{|l|l|c|}
\hline No & \multicolumn{1}{|c|}{ Variabel } & Pernyataan \\
\hline 1 & Pelayanan Pelanggan & 6 \\
\hline 2 & Kualitas Produk & 7 \\
\hline 3 & Kebijakan Harga & 4 \\
\hline 4 & Fisik Toko & 6 \\
\hline 5 & Kesadaran & 5 \\
\hline 6 & Kepercayaan Pengecer & 8 \\
\hline 7 & Loyalitas & 4 \\
\hline
\end{tabular}

\section{Hasil Uji Statistik}

Uji Validitas. Pada hasil uji validitas telah didapatkan angka pada setiap variabel > 0,7 pada nilai loading factor kecuali pada variabel kebijakan harga,kesadaran, kepercayaan pengecer, dan loyalitas. Nilai Average Variance Extracted (AVE) yaitu > 0,5 maka semua variabel yang digunakan sudah valid.

Uji Reliabilitas. Pada hasil reliabilitas, maka berdasarkan hasil yang telah diolah oleh program SmartPLS 3, dinyatakan bahwa angka pada nilai Cronbach's Alpha dan Composite Reliability yaitu > 0,6 maka variabel pada penelitian ini sudah reliabel.

Pengujian Konstruk Penelitian. Nilai R-square $\left(\mathrm{R}^{2}\right)$ yang dihasilkan pada variabel kepercayaan pengecer sebesar 0,560 memiliki arti sebesar 56\% (bersifat moderat). Pada variabel loyalitas memiliki nilai 0,294 yang berarti sebesar 29,4\% (bersifat lemah). Pada hasil nilai effect size $\left(\mathrm{f}^{2}\right)$ dijelaskan variabel pelayanan pelanggan dengan nilai sebesar 0,093 (tergolong besar), variabel kualitas produk dengan nilai sebesar 0,027 (tergolong sedang), variabel kebijakan harga dengan nilai sebesar 0,047 dan variabel fisik toko dengan nilai sebesar 0,097 (tergolong besar), kemudian pada variabel kesadaran dengan nilai sebesar 0,000 (tergolong kecil), pada variabel mediasi yaitu kepercayaan pengecer dengan nilai sebesar 0,417 (tergolong besar) dan memiliki efek terhadap variabel depenen yaitu loyalitas (loyalty). Berdasarkan nilai predictive relevance $\left(\mathrm{Q}^{2}\right)$ dijelaskan bahwa nilai variabel kepercayaan pengecer sebesar 0,260 (relevansi prediktif sedang). Kemudian, nilai dari variabel loyalitas sebesar 0,147 (relevansi prediktif lemah), tetapi variabel tersebut telah memenuhi syarat relevansi prediksi yaitu $>0$. 
Tabel 2. Hasil Pengujian Hipotesis

\begin{tabular}{|c|c|c|c|c|}
\hline Kode & Hipotesis & $\begin{array}{c}\text { T } \\
\text { statistics }\end{array}$ & P values & Kesimpulan \\
\hline H1 & $\begin{array}{c}\text { Pelayanan Pelanggan } \rightarrow \\
\text { Kepercayaan Pengecer }\end{array}$ & 2,802 & 0,005 & Diterima \\
\hline H2 & $\begin{array}{c}\text { Kualitas Produk } \rightarrow \\
\text { Kepercayaan Pengecer }\end{array}$ & 1,747 & 0,081 & Ditolak \\
\hline H3 & $\begin{array}{c}\text { Kebijakan Harga } \rightarrow \\
\text { Kepercayaan Pengecer }\end{array}$ & 2,520 & 0,012 & Diterima \\
\hline H4 & $\begin{array}{c}\text { Fisik Toko } \rightarrow \text { Kepercayaan } \\
\text { Pengecer }\end{array}$ & 3,115 & 0,002 & Diterima \\
\hline H5 & $\begin{array}{c}\text { Kesadaran } \rightarrow \text { Kepercayaan } \\
\text { Pengecer }\end{array}$ & 0,159 & 0,874 & Ditolak \\
\hline H6 & $\begin{array}{c}\text { Kepercayaan Pengecer } \rightarrow \\
\text { Loyalitas }\end{array}$ & 9,348 & 0,000 & Diterima \\
\hline
\end{tabular}

\section{DISKUSI}

Berdasarkan hasil pengujian pertama menjelaskan bahwa pelayanan pelanggan prediksi positif yang signifikan dengan kepercayaan pengecer pada pelanggan IKEA di Alam Sutera yang berarti H1 tidak ditolak. Hal ini sesuai dengan penelitian Anselmsson J., Burt S., \& Tunca B. (2017) menggambarkan bahwa pelayanan pelanggan memiliki pengaruh terhadap kepercayaan pengecer. Selanjutnya, didukung oleh penelitian Kursunluoglu E. (2014) menjelaskan bahwa pelayanan pelanggan tidak dapat sepenuhnya mendukung terjadinya kepercayaan terhadap pelanggan ataupun pengecer.

Hasil pengujian hipotesis yang kedua menjelaskan bahwa kualitas produk merupakan prediksi negatif yang signifikan dengan kepercayaan pengecer pada pelanggan IKEA di Alam Sutera yang berarti H2 ditolak. Didukung oleh peneliti sebelumnya Anselmsson J., Burt S., \& Tunca B. (2017) bahwa kualitas produk merupakan pengaruh yang membantu kepercayaan pengecer dan loyalitas terhadap toko karena kualitas dari produk sangat penting. Kemudian, penelitian yang mendukung yaitu Shih-Tse Wang, E., \& Tsai, B. K. (2014) menyatakan persepsi kualitas produk secara positif mempengaruhi kepercayaan terhadap pengecer karena kualitas layanan berguna untuk mengevaluasi keseluruhan interaksi pada pelayanan pelanggan.

Berdasarkan hasil pengujian hipotesis yang ketiga menjelaskan bahwa kebijakan harga merupakan prediksi positif yang signifikan dengan kepercayaan pengecer pada pelanggan IKEA di Alam Sutera yang berarti H3 tidak di tolak. Dalam penelitian Anselmsson J., Burt S., \& Tunca B. (2017) yang merupakan penelitian terdahulu untuk mendukung penelitian ini menjelaskan bahwa persepsi harga yang dirasakan pelanggan merupakan dimensi dari kebijakan penetapan harga. Selanjutnya, penelitian yang mendukung yaitu Lombart, C., \& Louis, D. (2014) bahwa kebijakan harga atau citra harga yang terdapat di dalam penelitian memiliki pengaruh yang positif terhadap kepribadian pengecer dan termasuk kepercayaan pada pengecer.

Hasil pengujian hipotesis yang keempat menjelaskan bahwa fisik toko merupakan prediksi positif yang signifikan dengan kepercayaan pengecer di IKEA Alam Sutera yang berarti H4 tidak ditolak. Hasil hipotesis acuan dari Anselmsson J., Burt S., \& Tunca B. (2017) yang menyatakan fisik toko memiliki pengaruh yang positif terhadap kepercayaan pengecer yang menjelaskan dimensi toko fisik merupakan dimensi dari brand equity, persepsi pelanggan 
tentang penampilan fisik toko merupakan kunci dari keseluruhan merek pengecer yang dapat memengaruhi niat pelanggan terhadap toko. Pengujian yang terdapat pada penelitian yang mendukung yaitu Alsaif, T. M., \& Ghoneim, A. (2015) juga membahas tentang variabel ini, variabel fisik toko sendiri memiliki Pelanggan yang percaya atas fisik toko dan dapat membantu memengaruhi kepercayaan kepercayaan mereka.

Hasil pengujian hipotesis kelima menyatakan bahwa kesadaran merupakan prediksi negatif yang signifikan dengan kepercayaan pengecer di IKEA Alam Sutera yang berarti H5 tidak ditolak. Hasil dari Anselmsson J., Burt S., \& Tunca B. (2017) yang menyatakan bahwa kesadaran gagal menjelaskan perannya sebagai dimensi yang berkaitan dengan dimensi lainnya yang berarti dimensi kesadaran tidak memiliki efek langsung pada kepercayaan ritel. Selanjutnya, penelitian yang mendukung dari Das, G (2016) menjelaskan kesadaran memiliki pengaruh positif terhadap kepercayaan yang berarti kesadaran pengecer membantu pembeli mengenali pengecer dalam beberapa kondisi seperti pengakuan toko.

Hasil pengujian hipotesis keenam menyatakan bahwa kepercayaan pengecer merupakan prediksi positif yang signifikan dengan loyalitas di IKEA Alam Sutera yang berarti H6 tidak ditolak. Hal ini sesusai dengan Anselmsson J., Burt S., \& Tunca B. (2017) menyatakan kepercayaan pengecer sebagai mediasi mempengaruhi secara signifikan terhadap loyalitas, dengan adanya kepercayaan terhadap suatu merek atau toko maka akan menimbulkan loyalitas pelanggan pada toko tersebut. Selanjutnya, terdapat hasil pengujian hipotesis dari penelitian Rubio N, Villaseñor N \& Yagüe M.J yang menjelaskan bahwa kepercayaan pengecer memiliki pengaruh positif secara langsung terhadap loyalitas yang dimana seseorang akan melakukan pembelian kembali atau mempromosikan IKEA dengan sukarela karena sudah menaruh kepercayaan yang tinggi.

\section{PENUTUP}

Populasi yang tidak terbatas dalam penelitian ini, sehingga pengambilan sampel dilakukan secara acak dengan menggunakan metode convenience sampling. Variabel-variabel yang digunakan untuk memprediksi loyalitas pada penelitian ini hanya terbatas pada variabel pelayanan pelanggan, kualitas produk, kebijakan harga, fisik toko, kesadaran, dan kepercayaan pengecer. Mahasiswa yang ingin meneliti lebih lanjut diharapkan untuk menambahkan variabel baru lainnya seperti purchase intention dan promotion, memperbanyak sampel, dan memperluas wilayah populasi.

\section{DAFTAR PUSTAKA}

Alsaif, T. M., \& Ghoneim, A. (2015). Trust transference from brick to click retailers: a conceptual model for impersonal trust. 48th Hawaii International Conference on System Sciences, 3336-3343. IEEE.

Anselmsson, J., Burt, S., \& Tunca, B. (2017). An integrated retailer image and brand equity framework: Re-examining, extending, and restructuring retailer brand equity. Journal of retailing and consumer services, 38, 194-203.

Burt, S., \& Carralero-Encinas, J. (2000). The role of store image in retail internationalisation. International Marketing Review, 17(4/5), 433-453.

Cronin, Jr, J.J. and Taylor, S.A. (1992), "Measuring service quality: a reexamination andextension" Journal of Marketing, Vol. 56, pp. 55-68. 
Das, G. (2014). Linkages of retailer awareness, retailer association, retailer perceived quality and retailer loyalty with purchase intention: A study of Indian food retail brands. Journal of Retailing and Consumer Services, 21(3), 284-292.

(2016). Antecedents and consequences of trust: an e-tail branding perspective. International Journal of Retail \& Distribution Management, 44(7), 713-730.

Do Vale, R. C., Matos, P. V., \& Caiado, J. (2016). The impact of private labels on consumer store loyalty: An integrative perspective. Journal of retailing and consumer services, 28 , 179-188.

Grewal, R., Cote, J. A., \& Baumgartner, H. (2004). Multicollinearity and measurement error instructural equation models: Implications for theory testing. Marketing Science, 23(4), 519-529.

Hair, J. F., Sarstedt, M., Ringle, C. M., \& Mena, J. A. (2012). An assessment of the use of partial least squares structural equation modeling in marketing research. Journal of the academy of marketing science, 40(3), 414-433.

Ringle, C. M., \& Sarstedt, M. (2011). PLS-SEM: Indeed a silver bullet. Journal of Marketing theory and Practice, 19(2), 139-152.

Halim, P., Swasto, B., Hamid, D., \& Firdaus, M. R. (2014). The Influence of Product Quality, Brand Image, and Quality of Service to Customer Trust and Implication on Customer Loyalty (Survey on Customer Brand Sharp Electronics Product at the South Kalimantan Province). European Journal of Business and Management, 6(29), 159-166.

Henseler, J., Ringle, C. M., \& Sinkovics, R. R. (2009). The use of partial least squares path modeling in international marketing. In New challenges to international marketing, 277319. Emerald Group Publishing Limited.

Koo, D. M. (2003). Inter-relationships among store images, store satisfaction, and store loyalty among Korea discount retail patrons. Asia Pacific Journal of Marketing and Logistics, $15(4), 42-71$.

Kursunluoglu, E. (2014). Shopping centre customer service: creating customer satisfaction and loyalty. Marketing Intelligence \& Planning, 32(4), 528-548.

Lombart, C., \& Louis, D. (2014). A study of the impact of Corporate Social Responsibility and price image on retailer personality and consumers' reactions (satisfaction, trust and loyalty to the retailer). Journal of retailing and consumer services, 21(4), 630-642.

MacKinnon, D. P., Fairchild, A. J., \& Fritz, M. S. (2007). Mediation analysis. Annu. Rev. Psychol., 58, 593-614.

Maholtra, N.K.K. (2004). Marketing Research: An Applied Orientation, Fourth Edition, New Jersey: Pearson Education. (2010). Marketing Research: An Applied Orientation, Sixth Edition.

Moriuchi, E., \& Takahashi, I. (2016). Satisfaction trust and loyalty of repeat online consumer within the Japanese online supermarket trade. Australasian Marketing Journal (AMJ), 24(2), 146-156.

Orel, F. D., \& Kara, A. (2014). Supermarket self-checkout service quality, customer satisfaction, and loyalty: Empirical evidence from an emerging market. Journal of Retailing and Consumer Services, 21(2), 118-129.

Razak, I., Nirwanto, N., \& Triatmanto, B. (2016). The impact of product quality and price on customer satisfaction with the mediator of customer value. Journal of Marketing and Consumer Research, 30(1), 59-68.

Roscoe, J.T. (1975) Fundamental Research Statistics for the Behavioural Sciences, 2nd edition. New York: Holt Rinehart \& Winston. 
Rubio, N., Villaseñor, N., \& Yagüe, M. J. (2017). Creation of consumer loyalty and trust in the retailer through store brands: The moderating effect of choice of store brand name. Journal of Retailing and Consumer Services, 34, 358-368.

Sathyamoorthi, C. R., \& Mburu, P. T. (2016). An Analysis of Supermarket Pricing: The Case of Selected Supermarkets in Gaborone, Botswana. Journal of Management Research, 8(2), 66-74.

Shih-Tse Wang, E., \& Tsai, B. K. (2014). Consumer response to retail performance of organic food retailers. British Food Journal, 116(2), 212-227. 